\title{
correspondence
}

\section{Dismantling DNA regulations}

SIR,--I am delighted that John Maddox has taken up the debate on the problems related to regulations governing genetic manipulation (1 March, page 10). His analysis of the situation is perceptive when he states that the choice, if GMAG's procedures don't change soon, will be only whether to work with NIH guidelines here or elsewhere. In this regard John Maddox and I probably disagree only on time scale. He clearly feels that all may be resolved by the end of 1980 and asks if this is not enough, is it "a chance worth taking"?

If we are going to gamble we must know the odds and the stakes. At stake is the future of most genetic manipulation work in this country. The odds are heavily against anyone trying to continue in this highly competitive field if work has to be conducted under regulations so much more restrictive than elsewhere.

It is particularly bitter irony to find myself grouped with those scientists who invited constraints four years ago. That group was dominated by US scientists who are now working under relaxed NIH guidelines, while their colleagues here languish in the aftermath of their public outburst. From the outset, I have thought that those who invited constraints were doing both science and the public a huge disservice; I see no evidence to change my mind. A bureaucracy has been established and will be hard, if not impossible, to dismantle rationally.

In attacking the NIH guidelines, John Maddox subscribes to currently fashionable scare stories, those of "conjectured immunological hazards" and other problems "of expression". In fact when we talk of known proteins we can estimate possible dangers because we handle the proteins in their regular environment. We can therefore assess how to take precautions in handling the same products in genetic manipulation experiments. Such decisions, at least at the research laboratory level, are a matter of day-to-day care and not a matter for committee rulings and elaborate bureaucratic procedures. If there were risks which could be quantified and if there were a need for regulations which which could be formulated rationally, then we might start to build from scratch. Unfortunately, we are not in a position to build, but rather in the position of dismantling excessively restrictive. empirically conceived, regulations.

If w'e were to accept the idea of dismantling the regulations by rational means we could fall into an expensive trap. Any conjectured risk would need to be quantified and the limit to conjecture and to expense involved in collecting the necessary data cannot be foreseen. What I asked for previously was an acceptance of the spirit of the NIH guidelines. Let us recognise the need for care when there is a known hazard, but let us not get lost in a morass of conjectured risks. Yours faithfully, Alin R. Williamson

\section{Mediterranean scientists stymied by bureaucrats}

SIR,-Rather than focus on who attacked UN research programmes on the Mediterranean at the recent Geneva Conference of the Mediterranean States (15 February, page 506), and who succeeded in cutting three scientific research projects of major importance, one should analyse who failed (and why) to support the scientific component of the Mediterranean Action Plan (MAP). Incidentally, this component has been fully in line with the proclaimed "target areas" of the Group of 77 and of the UN system, among which the "reinforcement of scientific and technological capacities of the developing countries" is foremost.

That research results, produced by the 83 -odd laboratories of the region. are still inferior in quality compared to those from (for example) Liverpool. Woods Hole. or Villefranche-sur-Mer, would hardly surprise anybody. Obviously, in recent years something different from competing with the centres of excellence has been attempted. Recently it became clear that this implicit aim has met with considerable success. At the November 1978 joint ICSEM-UNEP Review Meeting on the Mediterranean Pollution Research Pilot Projects, held at Antalya. Turkey, a large number of interesting contributions were reported. These came from many laboratories never before known to produce anything of international significance. UNEP's contribution to the execution of these programmes was in the form of equipment, training fellowships, and travel and subsistence support for such meetings. It never amounted to more than some 10 ". of the total on-the-spot expenditure for the participating laboratories' projects. However, its importance should be judged by the fact that it mobilised sizeable national resources for research in marine sciences in many developing countries; but, unfortunately, not in all. The latter, instead of asking for additional help in creating national research centres, have joined the ranks of critics of the programmes, although for different reasons.

The UNEP-sponsored and -catalysed multilateralism in scientific training. technical cooperation and data exchange, has indicated, for better or worse. the eclipse of the old northern paternalism. Fven the well produced 'show-biz' contribution to the Antalya meeting by one of the most developed countries of the region, has not, and probably would not reverse this trend. It has become apparent that all around the Mediterranean there is emerging a broadly based international community of marine scientists, which is procuring the necessary atmosphere for appraisal of scientific data, for discussion of results, and for mutual understanding irrespective of present day political or conomic disagreements. The bureaucrats, a large majority in the ranks of the 60 or so official governmental representatives at the Geneva Conference, have seen the old. more-or-less comfortable order vanish, and see themselves increasingly made superfluous by the internationally oriented groups of scientists. The latter, as well known from experience, are difficult to control: they will soon be asking for more money, and will generally become a pain in the neck. Thus the hatchet was used, not surprisingly, on those who have produced the only tangible result in the four years of this unique exercise called MAP. Conversely, and in line with this thinking, a boost has been given to appealing, but vaguely defined, future plans. Among these, as Dr Walgate has correctly indicated, the development of alternative energy sources by the less developed countries has been accepted as one of the short term priorities.

The Geneva Conference was, in a way. a scaled down rehearsal for the

UNCSTD. The message is clear and fully supports Moravcsik's admonition: do not let scientific and technological issues be decided by bureaucrats alone. Yours faithfully, Velimir Pravdic

Ruder Boskovic Institute,

Zagreb, Yugoslavia.

\section{Cooperation in German health programme}

SIR,-In his article about research in Germany (8 February, page 423) Robert Walgate refers to the federal government's programme on promoting research and development in the service of health 1978-1981 and to some worries of officials of the German research society (DFG). I am afraid there has been a misunderstanding, since there is no conflict between DFG and the federal ministries responsible for the health research programme.

When setting up the government programme, DFG and the federal government agreed that a close cooperation should take place. This is routine by now, DFG officials taking part in assessment meetings and quite of ten making valuable suggestions. In addition to this we have asked DFG to inform the government whenever they have the feeling that a project in health research is being funded by the federal government although the scientific quality does not seem to be sufficient. No example has been reported so far.

It is obvious that only research of good scientific quality should have an impact on government policy: poor research would do more harm than good. However, the federal ministries reserve the right not to fund a research project if it is likely that possible results would not have any bearing on the work of the ministries. In these cases, which happen quite often, the applicants are advised to submit their proposals to DFG or other institutions which do not have the same restrictions as we have, and whose financial means are not changed by the arrival of the new programme.

Yours faithfully,

HANS P. LORENZEN

Federal Ministry for Research and

Technology, Bonn, West Germany. 